\title{
7. Press freedom and the High Court in the Callinan era: Rethinking the rhetoric
}

\section{ABSTRACT}

Justice Ian Callinan, appointed to the Australian High Court in 1998, challenged the rhetoric on the media's role in society and its claims to press freedom with his minority decision in the Lenah Game Meats case in 2001. He questioned the notion of media freedom in an age where information providers are multinational corporations with a vested interest in the sale of news. Further, he challenged the claim of news organisations to special privileges on public interest grounds to the detriment of the rights of others. This paper uses qualitative analysis techniques to consider the comments of Justice Callinan and Justice Michael Kirby in the Lenah Case and four subsequent media-related cases in an attempt to develop a theory about the attitudes of these High Court justices towards the media. It finds five key themes emerging from their decision, headed by the expression 'The Modern Media', used by both Justice Callinan and Justice Kirby, which embodies many of these attitudes. The other key themes are the shift to considering media 'just another business', the self-appointed role of judges as reporting experts, the ascendancy of privacy over press freedom, and the challenge to some legal privileges with which the media have become comfortable.

\section{MARK PEARSON}

Bond University, Queensland 


\section{Background and introduction}

W

HEN Australian High Court Justice Ian Callinan handed down his minority decision in the Lenah Game Meats case in November 2001 , he took the opportunity to do much more than deal with the legal technicalities of the issues at stake. Rather, he offered his views on the media in modern society, drawn from personal observations, particularly from decades spent as a Brisbane QC specialising in media law. His points included these:

- The media's position of independence has become ambiguous as the boundaries between news and comment, advertising and information, and journalism and government have blurred (para 254).

- The commercial value of information needs to be factored into discussions of, and judgments about, freedom of expression and related issues (para 256).

At the same time as publishing technologies have expanded, ownership and control of media organizations has become more concentrated and is a matter of public concern (para 258).

- While the expression 'marketplace of ideas' is used to justify free speech, it actually means everyone should have access to express their ideas in the public domain. Concentration of media control prevents this (para 261).

- The media's claim to freedom of the press had taken on an 'air of dogma', as if this was a right superior to all other rights (para 273).

His decision to share his views on the media with the broader community was clearly a calculated one. It followed the ebb and flow of free speech cases throughout the 1990s where the High Court read an implied freedom to communicate on matters of politics and government into our Constitution which at one stage introduced a whole new defence to defamation (Theophanous Case, 1994) and later reverted to an adaptation of an existing defence (Lange Case, 1997) which is still being modified. Justice Callinan has made it clear in several decisions that he is opposed to this development.

The 20,849 word Callinan decision in Lenah Game Meats was dismissed by some as the spleen-venting ramblings of a renegade conservative judge, a Howard Government appointee. Freedom of the press is a black and white issue and you are either with us or against us, they bleated. Yet, on reflection, some of his observations were remarkably similar to those which have emanating from more liberal, critical, even Left-leaning quarters over the past 
couple of decades. They too have pointed out the problems of the commercialisation of news, the corporatisation of the newsroom, the concentration of media ownership, and the high-level mateship between politicians and owners.

Just last year on the 100th anniversary of the High Court, a commentary in The Australian Financial Review (Clark: 1) warned us not to stereotype High Court justices. Some might seem like leopards when appointed, but their spots change in quite complex ways once they assume their roles, with some being liberally minded but jurisprudentially conservative, and others adopting positions one might never have predicted.

This pilot study systematically analyses Justice Callinan's comments in that case and four other media-related cases since then, along with those of Justice Michael Kirby as a counterpoint for this article, with a longer term aim to analyse all judges' comments in the selected cases.

Judges' individual remarks in court cases, their obiter dicta, are normally considered secondary to their key legal reasons for reaching their decisions, their ratio decidendi. This study's concern is less with their decisions in these cases, and more with the language and logic they have used in talking about the media and free speech in reaching those decisions.

\section{Research question}

The key research question for the project is:

What do the High Court judgments in five recent cases involving media or free speech issues tell us about the court's attitudes to the media, journalism and press freedom?

(As mentioned, Stage 1 focuses on the judgments of Callinan J. and Kirby J.)

\section{Literature}

While the grounded theory method used here requires no analysis of the previous literature in the area, there is already some academic material appearing on these cases, and undoubtedly more will be published over coming months. Articles on the Lenah Game Meats case to date include the anti-media polemic of Taylor and Wright in the Melbourne University Law Review (2002) and an instructive breakdown of the case for media practitioners by Sarre (2003) in the Australian Journalism Review. I have co-authored an analysis of the Gutnick case in the same edition (Pearson, Proud and Willcox, 2003). 


\section{Methodology}

Given that any analysis was to be a conceptual and a linguistic one, with minimal scope for quantitative material, it was decided the best method to use, at least for this first stage, was an adaptation of the grounded theory approach to qualitative research first expounded by Glaser and Strauss (1967) and later refined by Strauss (1987), Strauss and Corbin (1990 and 1994), and Glaser (1992). The text of the decisions by Callinan J. and Kirby J. across five cases dealing with media and free speech cases were fed into the qualitative interactive database software NUD*IST, the operation of which is explained by its originators, Richards and Richards (1998).

The grounded theory process involves extended analysis over a range of stages. Its founders called it the "constant comparison method of qualitative analysis' (Glaser and Strauss,1967, p. 106). Specific techniques of analysis include the techniques of open coding, axial coding and selective coding as well as the display technique of the conditional matrix.

Strauss and Corbin (1990, p. 61) defined 'open coding' as 'the process of breaking down, examining, comparing, conceptualising and categorising data'. It involves the labelling of phenomena (Strauss \& Corbin, 1990: 63), the discovering of categories (Strauss \& Corbin, 1990, p. 65), the naming of categories (Strauss \& Corbin, 1990: 67), the developing of categories in terms of their properties and dimensions (Strauss \& Corbin, 1990: 69) and the writing of code notes (Strauss \& Corbin, 1990: 73). The categories are formed through the labelling and grouping of similar incidents (Strauss \& Corbin, 1990: 74). Axial coding involves the drawing of comparisons between data, while selective coding elevates the theory above the data, moving from description to conceptualisation (Strauss \& Corbin, 1990: 120).

Strauss (1987: 64) noted that the researcher had to make an important choice to code more intensively around particular categories. This focus became the 'axis' of the category being studied, with comparisons being made between this and other categories, building up a 'dense texture of relationships'. This takes the coding process to a new depth and closer to the development of theory. Strauss and Corbin (1990, p.96) defined 'axial coding' as:

A set of procedures whereby data are put back together in new ways after open coding, by making connections between categories. This is done by using a coding paradigm involving conditions, context, action / interactional strategies and consequences. 
Axial coding is where the conceptual demands upon the researcher become more complex because it is an iterative process of inductive and deductive thinking, involving repeated comparisons and questioning (Strauss \& Corbin, 1990: 114). The key to it is the linkage of subcategories to a category using a set of relationships denoting causal conditions, phenomena, context, intervening conditions, action/interactional strategies and consequences (Strauss \& Corbin, 1990: 99).

The proponents of grounded theory also support the use of visual devices to help formulate and articulate relationships among and within categories. Strauss and Corbin (1990: 158) define the 'conditional matrix' as

An analytic aid, a diagram, useful for considering the wide range of conditions and consequences related to the phenomenon under study. The matrix enables the analyst to both distinguish and link levels of conditions and consequences.

After such an intensive process of coding and analysis, the researcher should be able to articulate a key theory which emerges from the data, some new insight which has been achieved through these empirical stages.

\section{Results}

The text of both Callinan J.'s and Kirby J.'s decisions in five recent media or free speech cases was saved and input into the NUD*IST software.

The cases were:

Lenah Game Meats Case (2001): Australian Broadcasting Corporation v Lenah Game Meats Pty Ltd [2001] HCA 63 (15 November 2001). Online. Available www.austlii.edu.au (Accessed 14 October 2003). [An ABC appeal against an interlocutory injunction by the Full Court of the Supreme Court of Tasmania restraining it from broadcasting footage of a brush tail possum abattoir.]

Gutnick Case (2002): Dow Jones \& Company Inc. v Gutnick [2002] HCA 56 (10 December 2002). Online. Available www.austlii.edu.au (Accessed 13 October 2003). [An international media publisher appeal against having to face defamation proceedings in Victoria, Australia, over material published from its web server in New Jersey, USA.]

Roberts' Case (2002): Roberts v Bass [2002] HCA 57 (12 December 
THE PUBLIC RIGHT TO KNOW

2002). Online. Available www.austlii.edu.au (Accessed 14 October 2003). [An appeal by the author and distributor of defamatory political pamphlets centring on the defamation defence of qualified privilege and its constitutional version as defined in Lange's Case (1997).]

Rivkin Case (2003): John Fairfax Publications Pty Ltdv Rivkin [2003] HCA 50 (10 September 2003). Online. Available www.austlii.edu.au (Accessed 14 October 2003). [Appeal over whether the NSW Court of Appeal was justified in overturning a jury's findings in a defamation trial.]

Rogers' Case (2003): Rogers v Nationwide News Pty Ltd [2003] HCA 52 (11 September 2003). Online. Available www.austlii.edu.au (Accessed 14 October 2003). [Appeal over the operation of the defamation defence of fair protected report of court proceedings and the NSW Court of Appeal's rationale for reducing damages awarded.]

The initial open coding process resulted in the development of 24 categories and sub-categories, and during the axial coding process these were reduced to nine intermediate categories. After further conceptualising during the final selective coding stage, some areas of overlap were identified between those nine intermediate categories which were finally reduced to five key themes, falling under the banner of 'The Modern Media', taken from an expression used by both Justices Callinan and Kirby. They were:

i. The 'Modern Media': Multi-national, high-tech, business-focused, concentrated ownership, powerful and well connected.

ii. Just Another business: Eye on the dollar rather than public service, primary duty to shareholders.

iii. Judges as reporting experts: Requiring facts over comment, 'reasonable' inquiries, and determinants of 'quality' media products.

iv. Privacy over press freedom: Entertaining the notion of a tort of privacy, distinguishing First Amendment, questioning Victoria Park Racing and Lange cases.

v. Challenging media privileges: Encouraging prior restraint, destabilising fair report protection, questioning whether newspapers produced in 'special circumstances'.

\section{Discussion}

Rather than venture into an exhaustive discussion under each of the five key 
thematic headings to emerge, for the purposes of this paper I propose to give you no more than a taste by way of two or three examples which have led to categorisation under each. These ideas will be fully expounded if research grant applications to pursue the full project are successful.

The 'Modern Media': Multi-national, high-tech, business-focused, concentrated ownership, powerful and well connected.

The expression 'the modern media' was used six times in the Lenah Game Meats case, five times by Justice Kirby and once by Justice Callinan. Justice Kirby spoke of the "new situations presented by the operations of modern media' (text unit 2203), 'judicial remarks written long before the features of the modern media and mass communications existed as they do today' (text unit 2232), and that 'the power of modern media, so important for the freedoms enjoyed in Australia, can sometimes be abused' (text unit 2234). Justice Callinan promised 'an overview of circumstances prevailing today with respect to current means of communication and intrusions upon privacy, and the practices, reach and resources of the modern media' (text unit 2696). The identification of this key category, using their own term, sums up their concern that the media's role in modern society has changed, and that laws need to change accordingly.

Justice Callinan (text units 2991-2993) flagged his discomfort with the 1990s free speech decisions to foreshadow his critique of the modern media:

just as members of this Court in Stephens and Lange referred to perceptions and matters not in evidence, I, too, intend to refer to a number of the realities of the modern publishing, entertainment and media industries.

He spoke of those media realities being 'to some extent inseparably intertwined' with the activities of executive government (text unit 2995), 'as each seeks to use the other for its own purposes' (text unit 3007). He also noted the 'influence that can be exerted by media owners whose interests span international borders and all or most forms of communication' (text units 4140-4141). Concentration of ownership was also 'a matter of great public concern' (text units 3048-3049).

Justice Kirby said the courts were the only institutions in society 'with the power and the will to provide protection and redress' when citizens are harmed 


\section{THE PUBLIC RIGHT TO KNOW}

by this powerful modern media (text units 548-551). He said the law of equity could be adapted to meet 'new situations presented by the operations of modern media' (text units 516-517). Both justices pointed to the advent of new technologies at the disposal of media organisations which had changed the landscape in which the media operated and, by implication, their relationship with the law (text units 411-423 and 3012-3017). Kirby reinforced this observation in the Gutnick case (text units 227-623).

In short, the elements of this key theme are that the modern media are quite different from media operating previously in that they are multi-national, hightech, business focussed, concentrated in their ownership, powerful, and intertwined with the operations of government. According to Australia's highest justices, these modern media call for new legal approaches and solutions and a re-examination of respective rights.

Just Another Business: Eye on the dollar rather than public service, primary duty to shareholders, chequebook journalism, cashfor comment, well resourced.

Others, most notably Julianne Schultz (1992 and 1998), have stressed the fact that the news media should not be regarded, particularly their owners, as 'just another business'. Their special position of trust invoking their Fourth Estate role as watchdogs on the governmental process meant that traditional business models should not apply to them.

This study has demonstrated that, while our High Court justices demonstrate an awareness of this sentiment, their impression is that media organisations are being run as 'just another business' over and above other so-called public obligations. Justice Callinan chose to highlight 'the advent and proliferation of "cheque book journalism" and the payment of "cash for comment" in his Lenah Game Meats judgment (text units 4144-4145). He also noted the blurring of reportage and entertainment in 'infotainment' and the disguising of advertising as 'infomercials' and 'advertorials' (text units $3002-3005$ ). He pointed to the cash value in the capturing of news by way of various media forms (text units 3023-3030). He even bundled the ABC into the equation as just another business by pointing to its competition with commercial broadcasters, the commercial value of its footage, and its funding dependent perhaps of ratings (text units 2943-2953).

He directly juxtaposed the media's public duties with their commercial obligations with this statement: 
The asserted urgency as often as not is as likely to be driven by commercial imperatives as by any disinterested wish to inform the public. It would be naive to believe that the media's priorities would be otherwise. If the presses and the video tapes have to roll at a certain hour, they will because large sums of money for space and time have changed hands between the publishers or broadcasters and advertisers whose contracts require that there be a newspaper published or a program presented, on time, so that their advertisements will be shown, rather than for any altruistic motives on the part of the publisher or broadcaster. It will be rare in fact that the public interest will be better served by partial truth and inaccuracy this Tuesday than balance and the truth on Friday week (text units 3181-3191).

In his Gutnick judgment (text units 2083-4), Justice Callinan specifically noted publishers' ultimate duties to their shareholders 'to maximise profits', indicating that as corporations this is where their allegiances truly lie.

Judges as reporting experts: Requiring facts over comment, 'reasonable' inquiries, and determinants of 'quality' media products.

At various points in these judgments, the justices took on the role as expert commentators on media practice, and as the determinants of what constitutes 'quality' in a media product.

In Lenah, Callinan chimed into the age-old debate of news versus comment by saying that in early newspapers they were 'desirably and responsibly divorced in expression' (text unit 2996). In the modern media, 'wholesale comment, speculatioin, informed and uninformed, on the part of authors of articles in daily newspapers seems to be encouraged', he lamented (text units 3239-3240). Almost all articles contained a 'spin' and even the most inexperienced reporters were awarded bylines, 'a practice almost unknown a generation or so ago' (text units 3243-3245).

In the Rivkin and Rogers cases, both Callinan and Kirby applied their own quality judgments upon the newspapers involved, the Sydney Morning Herald and the Australian Financial Review in the Rivkin case, and the Daily Telegraph in the Rogers case. In his Rivkin judgment, Kirby noted the Fairfax newspapers were 'generally accepted as serious journals'. They were 'journals of record' (text units 578-582). But in the Rogers case involving a Daily Telegraph story, Justice Callinan pointed out that there was 


\section{THE PUBLIC RIGHT TO KNOW}

no evidence whether, as is the case with some publishers of newspapers, the respondent made the claim that it was a publisher of journals of record, newspapers which recorded accurately the events of the day, and whose editions would serve as a reliable source of information for historians and others in the future. Whether that claim is made or not, the fact is that newspapers do, as has otherwise been claimed, provide a 'first rough draft of history' (text units 930-936).

These are but two examples. Across the various cases the justices position themselves as experts on the language and layout appropriate to be used in news stories, the timelines in which they should expect sources to comment on allegations, and the ethics of the pretext under which reporters convince a source to be interviewed. While this is to be expected in some defamation cases, these five recent cases have gone further than most others in dictating to reporters the kinds of practices which might be deemed acceptable and in sending messages to the community of what constitutes quality in journalism and publishing.

Privacy over press freedom: Entertaining the notion of a tort of privacy, distinguishing First Amendment, questioning Victoria Park Racing and Lange cases.

The cases also marked the renewed ascendancy of a potential right to privacy over the former weighting in favour of press freedom and a public right to know. Of course, other developments in recent times have reflected this development, most notably federal privacy legislation regulating the release of details about private individuals to the public. Again, the Lenah Game Meats case offered the most striking example of this development, with Justice Kirby leaving open the possibility of developing an actionable wrong for invasion of privacy (text units 603-604) and Callinan stating that 'the time is ripe' for considering it (text units ).

Both Justices Callinan and Kirby chose to leave open the question of whether the landmark 1937 decision in Victoria Park Racing and Rectreation Grounds Co Ltd v Taylor was a suitable precedent for the decisions which followed it in the privacy realm. In fact, Justice Callinan launched an extended argument as to why that decision was wrong and was at least an anachronism and why the minority views in that case were correct in their anticipation of television and its powerful role (text units 3706-3732). 
In opening the door for a tort of privacy, Callinan made the point that US privacy law was 'complicated by the First Amendment'. It was one of many mentions of that constitutional press freedom protector across the five cases, with Callinan at pains to point out that Australia's founding fathers chose not to have such an amendment to its constitution.

That said, Justice Callinan himself made the most explicit statement in favour of press freedom to arise in any of the judgments, when he said:

\begin{abstract}
All that I have said is not intended in any way to diminish the media or their role in modern society: it is merely to place them in context and proportion. Free speech, although it may sometimes have the ring of a slogan, is not to be disparaged. Despite what Wright J said in the Full Court of the Supreme Court, it is not a mere "glib cliche". It is a matter of fundamental importance in a democratic society. Any court which failed to appreciate that in any case in which a proposal to publish is threatened would be failing in its duty (text units 3308-3314).
\end{abstract}

In the Gutnick case, Justice Callinan criticised what he called the 'metaphor for free speech' - the marketplace of ideas - while casting his vote for an individual's right to reputation over freedom of speech:

Quite deliberately, and in my opinion rightly so, Australian law places real value on reputation, and views with scepticism claims that it unduly inhibits freedom of discourse (text units 2002-2015).

As noted earlier, Callinan repeatedly questioned the logic of the 1990s free speech decisions throughout his judgments on these cases, and was particularly critical of the High Court's 1997 Lange compromise judgment.

Challenging media privileges: Encouraging prior restraint, destabilising fair report protection, questioning whether newspapers produced in 'special circumstances'

The final major theme to emerge from the data involved some questioning of privileges the media have been granted in recent years. The major assault on the discretion against prior restraint came again from Justice Callinan in the Lenah Game Meats case. He stated clearly his doubts about 'the preferred treatment of the defence in defamation cases when applications for interlocutroy injunctions are made' (text units 4314-5).

PACIFIC JOURNALISM REVIEW 10 (1) 2004133 
The rationale offered for judicial caution is usually that free speech is precious beyond all other things, or that the defendant might be able to justify, or that the defendant might otherwise find a defence in qualified privilege, in short that the plaintiff might ultimately fail. There is nothing special about any of these matters except, perhaps, the first. (text units 4387-4391).

Although the data will fall within the next stage of this study, another strong example of the media being called into question about its special circumstances appeared in the joint judgment of Chief Justice Gleeson and Justice Gummow in the Rogers Case. At para 31 of that judgment, they note that Nationwide News had asked for account to be made for 'the circumstances in which daily newspapers are published'. The justices called for evidence of what such circumstances might be if they were to be an indication of whether or not they had behaved reasonably in the circumstances. They then go on to note, at para 32, that the court takes account of legitimate interests such as freedom of speech and reputation.

The legitimate commercial interests of the respondent are entitled to due consideration. But reasonableness is not determined solely, or even mainly, by those commercial interests. The respondent carries on its business with a view to making profits for the benefit of its shareholders.

This excerpt, from the decision of two other justices, indicates there might be more material to support these theories as the stage 2 analysis of other judges' comments unfolds.

\section{Towards a theory of the High Court and the 'Modern Media'}

There has been an identifiable shift in the High Court's attitude to media, journalism and free press principles, evident in these five recent judgments by Justices Callinan and Kirby. It is encapsulated in the term 'The Modern Media' used by both Justices Callinan and Kirby in their Lenah Game Meats judgments.

Its symptoms are the explicit questioning of previously established values and principles, including the media's Fourth Estate role, the special position of public trust it holds, its special circumstances of production, and its 'benefit 


\section{Conditional matrix: The High Court's 'MODERN MEDIA'}

\section{$20^{\text {th }}$ century media}

Press as $4^{\text {th }}$ Estate

Public right to know

Not just another business

Media's special circumstances of production

Shift to interpretive journalism

Caution with prior restraint

Fair and accurate court report

Old world production

‘Quality' not prejudged

\section{The 'Modern Media'}

Multinational corporations

Ascendancy of privacy

Just another business

Media's excuses questioned and require explanation.

Objective factual base needed

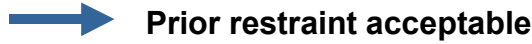

Needs further checks

Responsibilities with new tech

Priority for 'journals of record'

of the doubt' in the real world of public interest issues such as court reporting defences and prior restraint.

\section{Concluding questions}

Key questions arising include:

- Do we need new arguments about press freedom for this new era?

- Is the notion of press freedom and the public's right to know more complex than it has seemed in the past, demanding more detailed exposition?

- How can our notion of press freedom and the public's right to know accommodate this strong 21st century push for the individual's right to privacy, often promoted vigorously by the very people who might previously have been defenders of press freedoms?

- Is press freedom and the public's right to know taken seriously in media boardrooms, or is it just a device to shore up profits?

- Who should be defending press freedom and the public's right to know?

- Are the High Court perceptions reflecting those of society generally? 


\section{THE PUBLIC RIGHT TO KNOW}

It should first be noted that this is preliminary research only. Nevertheless, the reading of the cases indicates at the very least that there is no powerful voice left defending traditional notions of a free press and, as noted, there are some indications that other High Court justices are willing to air their own concerns about this value and issue their own challenges to it.

The High Court's statements demonstrate that press freedom is no longer sacrosanct, if it ever was so. Our highest jurists are questioning it and the privileges it invokes. It needs a new articulation in the modern era and perhaps some demonstrable accommodation of other values such as privacy.

Of course, those of us teaching media law need to train our students and journalistic colleagues to adapt their techniques to the new requirements. But more importantly, it requires serious attention to the judicial and public perception of the media and its role in modern society.

It needs a new language and line of argument because the old rhetoric is being both questioned and even attacked in our highest court. In many ways it has been left to 20th century bodies (some might argue 19th century bodies) like the Australian Press Council and the Australian Journalists Association, to defend press freedom with occasional submissions and public statements from academics and research groups. Harking back to old slogans will not suffice. Are there other powerful individuals or groups who even care about this value?

Perhaps the ultimate test is the extent to which media corporations believe the public has the right to know the complete truth about their own media operations. Those seeking transparency in society generally need to demonstrate it in their own corporate households.

Courts are supposed to reflect the views of society generally, but too often they are accused of holding elitist and lofty values. Nevertheless, perhaps this is one occasion when they might just have it right. This attitudinal shift cannot be dismissed as the rantings of a single judge. The ball seems to be in the court of those citizens who value the media's role in modern democratic society, and can come to the debate with clean hands. Please step forward.

\section{References}

Clark, Andrew. (2003, October 6). High Court shifts thinking. Australian Financial Review, p 1. 
Glaser, B.G. \& Strauss, A.L. (1967). The discovery of grounded theory: Strategies for qualitative research. New York: Aldine de Gruyter.

Glaser, B.G. (1992). Basics of grounded theory analysis. Mill Valley, CA.: Sociology Press.

Pearson, Mark, Carolyn Proud and Peter Willcox. (2003, July). The cyberboundaries of reputation: Implications of the Australian High Court's Gutnick decision for journalists. Australian Journalism Review, 25 (1): 101-114.

Richards, T. and Richards, L. (1998). Using computers in qualitative research. In Denzin, K and Lincoln, Y. (eds) (1998), Collecting and interpreting qualitative materials. Thousand Oaks, California: Sage. 211-245.

Sarre, Rick. (2003, July). Journalists, invasion of privacy and the High Court decision in Lenah Game Meats. Australian Journalism Review, 25 (1): 115-128.

Schultz, J. (1992). Investigative reporting tests journalistic independence. Australian Journalism Review, 14 (2): 18-30.

Schultz, J. (1998). Reviving the Fourth Estate. Democracy, accountability and the media. Cambridge: Cambridge University Press.

Strauss, A. \& Corbin, J. (1990). Basics of qualitative research. Grounded theory procedures and techniques. Newbury Park: Sage.

Strauss, A. \& Corbin, J. (1994). In N.K. Denzin \& Y.S. Lincoln (eds) Handbook of qualitative research ( $\mathrm{pp}$ 273-285). Thousand Oaks: Sage.

Strauss, A. (1987). Qualitative analysis for social scientists. Cambridge: Cambridge University Press.

Taylor, Greg and David Wright. (2002). Case Notes. Australian Broadcasting Corporatin v Lenah Game Meats. Privacy, injunctions and possums: An analysis of the High Court's decision. Melbourne University Law Review 36. Online. Available: www.austlii.edu.au/cgi-bin/disp.pl/au/journals/MULR/2002/36.html.

\section{Cases cited}

Lange Case (1997). Lange v Australian Broadcasting Corporation (1997) 189 CLR 520.

Theophanous Case (1994). Theophanous v Herald \& Weekly Times Ltd (1994) 182 CLR 104.

Lenah Game Meats Case (2001). Australian Broadcasting Corporation v Lenah Game Meats Pty Ltd [2001] HCA 63 (15 November 2001). Online. Available www.austlii.edu.au (Accessed 14 October 2003).

Gutnick Case. (2002). Dow Jones \& Company Inc. v Gutnick [2002] HCA 56 (10 December 2002). Online. Available www.austlii.edu.au (Accessed 13 October 2003).

Roberts Case (2002). Roberts v Bass [2002] HCA 57 (12 December 2002). Online. Available www.austlii.edu.au (Accessed 14 October 2003).

Rivkin Case (2003). John Fairfax Publications Pty Ltd v Rivkin [2003] HCA 50 (10 September 2003). Online. Available www.austlii.edu.au (Accessed 14 October 2003).

Rogers Case (2003).Rogers v Nationwide News Pty Ltd [2003] HCA 52 (11 September 
2003). Online. Available www .austlii.edu.au (Accessed 14 October 2003).

Dr Mark Pearson is Professor and Head of Journalism, Bond University, Queensland, and author of The Journalist's Guide to Media Law. This article was presented as a paper at at the third Public Right to Know (PR2K3) conference at UTS, 17-19 October 2003.

Mark_Pearson@bond.edu.au

\section{CALL FOR PAPERS: PUBLIC RIGHT TO KNOW CONFERENCE 2004}

The 2004 Public Right to Know conference will be held at the University of Technology, Sydney, over the weekend of 20-22 August 2004. This is the fourth in a series of annual conferences organised by the Australian Centre for Independent Journalism.

The theme for the opening night plenary session will be: The right to security vs the public right to know. We welcome a broad range of participants and papers from all relevant disciplines and professional fields. This year we will include two special themes, and we particularly welcome papers that address them:

1. What, if any, provision should an Australian republican constitution make for the media? In particular, should provision for independent public sector media be entrenched in a republican constitution, and should the ownership and operation of private sector media be regulated in any way?

2. Project Censored. What are the stories of social significance that are overlooked, under-reported or self-censored by our news media? The ACIJ will launch an Australian version of Project Censored, begun in the USA by Sonoma State University.

\section{MORE INFORMATION:}

More information on the conference is available at the PR2K website:

http://acij.uts.edu.au/pr2k/index.html 